\title{
Lazaroa
}

ISSN-e 1988-3307

\section{Notes on threatened plants of León (Spain), III}

Fermín del Egido ${ }^{1}$, María Fernández Cañedo ${ }^{1}$, Patricio Bariego ${ }^{2}$, Emilio Puente $^{1} \&$ María José López Pacheco $^{1}$

Received 31 March 2017 / Accepted 8 May 2017

Abstract. In this paper we provide new records and comments about 19 protected and/or threatened vascular plants in the province of León.

Keywords: Threatened plants; protected plants; Red Lists; chorology; León; Spain.

\section{[es] Notas sobre flora leonesa amenazada, III}

Resumen. En este trabajo aportamos citas nuevas y comentarios para 19 táxones de flora vascular protegida y/o amenazada de la provincia de León.

Palabras clave: Flora amenazada; flora protegida; Listas Rojas; corología; León; España.

\section{Introduction}

Knowledge and confirmation of existing populations as well as the search of new ones, is one of the threatened plants conservation basic pillars, but is frequently forgotten in conservation policies. As a continuation of previous papers (Egido \& al., 2012a, 2012b) we now provide new information about recent Leonese localities or comments about other previous reports, for 18 protected/threatened vascular plants.

All of them are included in the current Spanish Red List of Vascular Plants (from here on out LRFVE) (Moreno, 2008, 2010) and/or in Castilla y León plants protection laws (Anon., 2007a, 2015), either in the Priority Attention Plants Inventory of Castilla y León (from here on out IEAPCL) or in the Threatened Plants Index of Castilla y León (from here on out CEACL). Moreover, some of them are included in state protection laws (Anon., 2011), either in the Spanish Threatened Species Index (from here on out CEEA) or in the Wild Species Under Special Protection Index (from here on out LESRPE), or are also included in European protection laws in any annex of the Habitats Directive (Anon., 1992), which is transferred to the Spanish legislation by the law 42/2007 of Natural Patrimony and Biodiversity (Anon., 2007b).

The indexed material -when collected- is deposited in the Herbarium of the University of León (LEB). When we have collected testimony material, there have always been few specimens. For each report we provide the following data: locality (municipality, nearest town and place name, in this order), $1 \times 1$ Km UTM grid square (ED50 Datum), altitude, ecology, collection data, collector names and registration code in LEB, if available. Taxa are alphabetically ordered. Taxa names follow Flora Iberica (Castroviejo \& al., 19862016) except in the case of Spergula rimarum where we follow the criteria of Puente \& al. (1995).

\footnotetext{
Departamento de Biodiversidad y Gestión Ambiental. Área de Botánica. Facultad de Ciencias Biológicas y Ambientales. Universidad de León. Campus de Vegazana s/n. E-24071 León (España). E-mail: fegim@unileon.es, mfercn@unileon.es, empueg@unileon.es,mjlopp@unileon.es

2 Departamento de Botánica, Universidad de Salamanca, C/Licenciado Méndez Nieto s/n, E-37007 Salamanca (España). E-mail: BarHerPa@jcyl.es
} 


\section{Results and Discussion}

Aquilegia pyrenaica subsp. discolor (Levier \& Leresche) Pereda \& M. Laínz

León: Cabrillanes, Torre de Babia, between Laguna de Las Verdes and Peña Redonda, 29TQH3265, chionophilous basophilous grassland (Armerion cantabricae), $1955 \mathrm{~m}$ asl, 9-VII-2015, E. Puente \& F. del Egido (observed and photographed).

Cantabrian endemism included in the IEAPCL, of which in Egido \& al. (2012a, 2012b) we had compiled the existent leonese localities, as well as we had mentioned that it existed a report in Puerto de Pinos, near Peña Ubiña (Romero, 1983), not supported by any sheet and which had not been relocated again in that area. Finally, we have seen it in Babia's territories although not in that place but nearby Picos Albos, where there were lacking. This small population constitutes its occidental distribution limit.

\section{Armeria rothmaleri Nieto Fel.}

León: Sobrado, Cancela, strait of Covas (canyon of River Sil), 29TPH7807, rupicolous community (Saxifragion trifurcato-canaliculatae) in dolomitic limestone, 445-465 $\mathrm{m}$ asl, 29-IV-2014, F. del Egido \& P. Bariego (observed and photographed); Sobrado, La Barosa, tunnel of La Barosa, 29TPH7807, rupicolous community, dolomitic limestone, 490 m asl, 29-IV-2014, F. del Egido \& P. Bariego (observed and photographed).

Endemism of the southeast of León and east of Orense included in the CEACL, as well as in the LRFVE, in both cases under 'Vulnerable (VU)' category. It was already known from the strait of Covas (29TPH7806), but in Orense province (Giménez de Azcárate \& Amigo, 1996). The known localities in León are Peñarrubia -near the ones we indicate in this paper- and Montes Aquilanos (Peñas de Ferradillo and Doce Apóstoles) (Nieto Feliner, 1987).

\section{Baldellia alpestris (Coss.) M. Laínz}

León: San Emiliano, Riolago de Babia, Lago del Lago, 29TQH3854, interior of the tarn, 1744 $\mathrm{m}$ asl, 25-VIII-2004, E. Puente (LEB 84863); Boca de Huérgano, Portilla de la Reina, Hoyo Empedrado, 30TUN573648, interior and edge of the tarn, 2074 m asl, 02-VIII-2016, E. Puente, F. del Egido \& M. Cañedo (LEB 118069).

These are two new localities to be added to the three already known in the province (Egido \& al., 2012a, 2012b). This species is included in the IEAPCL.

\section{Callianthemum coriandrifolium Rchb.}

León: San Emiliano, Torrebarrio, Boca de Rolamuela (border between León and Asturias), 30TTN5771, chionophilous basophilous grassland (Armerion cantabricae), $2028 \mathrm{~m}$ asl, 13-VII-2016, E. Puente \& F. del Egido (LEB 118018). San Emiliano, Torrebarrio, Pico Colines, near the summit, 30TTN5869, chionophilous basophilous grassland (Armerion cantabricae), $2106 \mathrm{~m}$ asl,13-VII-2016, E. Puente \& F. del Egido (LEB 118019).

This taxon is included in the CEACL and in the LRFVE, in both of them under 'Vulnerable (VU)' category. Four populations of this rare species are known in León: Peñas de Faro, Peña Celleros, Pico Laguna and Ubiña massif (cf. Egido \& al., 2007). With the localities provided in this paper we confirm its presence in the Leonese hillside of Ubiña massif. Although the first of them is almost completely Asturian there are a few specimens which are in Leonese territories. Laínz (1960) reported this species in several localities in Ubiña massif, but all of them are apparently Asturian. The only one that might be Leonese is the report on 'Muesca de la Cigacha', an enclave situated between what we have listed, but in where we could not find it.

\section{Callitriche palustris L.}

León: San Emiliano, Riolago de Babia, Lago del Lago, 29TQH3854, interior of the tarn, $1744 \mathrm{~m}$ asl, 28-VII-2009, E. Puente \& F. del Egido (LEB 121112).

This species is included in the IEAPCL and in theLRFVE(underthecategory 'Endangered').In Egido \& al., (2007: 116, 2012a: 20, 2012b: 208) we had compiled the two known populations -three in fact, considering that we had accidentally not included the report of the Hoyo Empedrado (Alonso Redondo, 2003)-, and also added eight unknown populations in Omaña and in the centre and east of the Cantabrian Mountains in León. In this paper we provide a new one in lower Babia. 
Diphasiastrum alpinum (L.) Holub

León: Valdelugueros, Redipuertas, Puerto de Vegarada,30TTN978676, Calluna-Vaccinium heath (Carici asturicae-Callunetum vulgaris), $1628 \mathrm{~m}$ asl, 4-X-2011, F. del Egido \& E. Puente (observed and photographed); Valdelugueros, Redipuertas, Puerto de Vegarada, 30TTN975676, CallunaVaccinium heath (Carici asturicae-Callunetum vulgaris), 1630 m asl, 16-VII-2015, F. del Egido $\&$ P. Bariego (observed and photographed).

This species is included as 'Vulnerable (VU)' in the CEACL, and in the V annex of the Habitats Directive. Carlón \& al., (2014) compiled the four Leonese known populations (the only ones in Castilla y León). We now provide a fifth locality, where we find two small subpopulations approximately 300 metres separated from each other.

Epipactis fageticola (C.E. Hermos.) Devillers-Tersch. \& Devillers

León: Villaquejida, Villafer, Esla riverside, 30TTM8766, riparian forest dominated by Populus, $718 \mathrm{~m}$ asl, 21-VI-2015, P. Bariego (PB 5015).

This rare orchid has not been previously reported in León, being our record the first for the province. It is included in the IEAPCL.

\section{Eryngium duriaei J. Gay ex Boiss.}

León: Murias de Paredes, Barrio de la Puente, Suspirón, 29TQH320390, siliceous scree, $1757 \mathrm{~m}$ asl, 30-VI-2010, F. del Egido (LEB 105173); Murias de Paredes, Fasgar, Campo de la Ermita, 29TQH2243, grassland-broom communities, $1550 \mathrm{~m}$ asl, 4-VIII-1999, A. Fernández (LEB 120181); ibídem, Sierra de la Robeza, BoezaOmaña watershed, 29TQH2244, siliceous scree, $1810 \mathrm{~m}$ asl, 11-VIII-1998, A. Fernández (LEB 119285).

Endemism of Iberian northwest which is included in the IEAPCL, even though is common and locally abundant inside its distribution area. In León appears in Galician-Leonese mountains, as well as in western Cantabrian Mountains (from Ancares to low Babia and Luna territories) where it is more frequent than the bibliographic reports show. We add a few localities in Omaña territories (wherein it had not been reported yet), although its presence is higher.
Genista sanabrensis Valdés Berm., Castrov. \& Casaseca

León: Murias de Paredes, Barrio de la Puente, Suspirón, 29TQH320390, heath with gorse (Erico umbellatae-Genistetum sanabrensis), $1765 \mathrm{~m}$ asl, 30-VI-2010, F. del Egido (LEB 118069).

This northwestern Iberian endemism, which is included in the IEAPCL, has its main distribution centre in Galician-Leonese mountains (Sierra del Teleno, Montes Aquilanos, Sierra de la Cabrera, Sierra Segundera and Peña Trevinca massif), where is very frequent. Out of that area, it has only been found four isolated populations in western Cantabrian Mountains: one in Leonese territories in high Babia (Sierra de Villabandín in the municipality of Cabrillanes) (García González \& al., 1987), and three in Asturias (Degaña, Somiedo and Cangas del Narcea, although the first of them does not already exist) (Carlón \& al., 2010). In this paper we provide a small population in Omaña territories.

Isatis platyloba Link ex Steud.

León: Sobrado, Cancela, Covas strait (canyon of River Sil), 29TPH7807, grassland and rupicolous community (Saxifragion trifurcatocanaliculatae) in dolomitic limestone, $460 \mathrm{~m}$ asl, 29-IV-2014, F. del Egido \& P. Bariego (LEB 116198).

This species is included in the CEACL as well as in the LRFVE, in both cases under the 'Vulnerable' category. It is a northwestern Iberian endemism with most of its populations inside Castilla y León: at the canyons of the rivers Sil, Duratón, Riaza and Arribes del Duero (Galán Cela, 1993).

We have found an important and large population, in good state of conservation, at the canyon of River Sil which is near the previous known ones compiled in Amich \& Sánchez Rodríguez (1988): Peñarrubia reservoir, and between Corporales and Noceda de Cabrera. This discovery is important considering that Muñoz Centeno \& al. (2009) pointed out that 'the Leonese population in River Sil valley has not been found over the last few years'.

\section{Lychnis alpina L.}

León: San Emiliano, Torrebarrio, El Ronzón, 30TTN5866 and 30TTN5966, Calluna heath and grasslands, 1890-1950 m as1, 5-VII-2016, 
E. Puente, F. del Egido \& M. Cañedo (LEB 118005); San Emiliano, Torrebarrio, between Muesca de la Cigacha and Pico Colines, Ubiña massif, 30TTN5870, neutro-basophilous grassland, $1955 \mathrm{~m}$ asl, 13-VII-2016, E. Puente \& F. del Egido (LEB 118021).

This species is included in the IEAPCL. In Egido et al. (2012a) -where we made a compilation of this species localities- we accidentally forgot the ancient report (ut Viscaria alpina (L.) Don), at Peña Prieta massif (Monte de las Hijadas) (Losa \& Montserrat, 1954), as well as the recent one of Coriscao (Alonso Felpete $\&$ al., 2011) which was unknown for us in that moment.

We provide now two new populations in the Ubiña massif. The first of them is near or is possibly the same that the ancient one of Puertos de Riotuerto, in the south of Ubiña, at the border between Asturias and León (Laínz, 1960). In any case, we mention it here because is doubtlessly the population with the largest number of individuals in León and very likely of the Cantabrian Mountains. The other report is in Ubiña massif too, but four kilometres to the north approximately.

\section{Nigritella gabasiana Teppner \& E. Klein.}

León: Cabrillanes, Torre de Babia, Picos Albos, 29TQH3365, chionophilous basophilous grassland (Armerion cantabricae), $2100 \mathrm{~m}$ asl, 16-VII-2007, E. Puente (LEB 92479). Ibidem, near Montigüero, 29TQH334647, grassland in Calluna heath, in areas covered with snow for long time, $2087 \mathrm{~m}$ asl, 1-VII-2016, E. Puente \&. F. del Egido (observed and photographed); Villamanín, Casares de Arbás, Las Tres Marías, 30TTN7159, chionophilous basophilous grassland (Armerion cantabricae) beneath a calcareous face, $1910 \mathrm{~m}$ asl, 14-VIII-2009, F. del Egido (observed); Posada de Valdeón, Caín, Puertos de Cuba, 30TTN7159, 2100 m, chionophilous basophilous grassland (Armerion cantabricae) beneath a calcareous face, 10-VIII2011, F. del Egido (LEB 106333).

We provide three new Leonese populations of this Pyrenaical Cantabrian endemism which is included in the IEAPCL. Moreover, it is on the LRFVE under the 'Less Conservation' category.

In León it is known from several dispersed localities: Villargusán, Peña Ubiña Pequeña, Collada de Aralla, Cármenes, Pico Huevo and Puerto de San Isidro (Galán Cela \& al.,
1991, ut $N$. nigra, Nava \& al., 1994a, 1994b). More recently it has been reported on Peña Ten (Lence, 2009), Mampodre (Lence \& al., 2010) and on two localities of the upper Torío river basin -which specify the general report in Cármenes (Egido, 2012).

The population in Torre de Babia that we point out in this paper constitutes -together with Asturian populations of Somiedo (Nava \& al., 1994a)- the occidental distribution limit for the species. We also confirm its presence in Leonese territories of Picos de Europa National Park since Galán \& al. (1991) consider as Leonese a report on Peña Remoña (ut. $N$. nigra), at 2000 metres, which in fact is in Cantabria and so it is contemplated in Nava \& al. (1994a), and in Alonso Felpete \& al. (2011) is included a report on Collado Areniza which is highly probable in Asturias. Finally, it is necessary to precise that population referred in Pico Huevo would really be in Puerto de Vegarada-Peñas de Faro, where we have seen several subpopulations between 1670-2000 m asl. Pico Huevo is a siliceous mountain where this orchid does not live.

Nothobartsia spicata (Ramond) Bolliger \& Molau

This species is included in the LRFVE under 'Vulnerable (VU)' category. We only want to indicate that Alonso Felpete \& al. (2011) compiled two Picoeuropean localities, which are not contemplated for León in Benedí (2009). Both of them would be the only ones in Castilla y León and considering this they should be included in the CEACL as 'Vulnerable' at least.

\section{Orchis papilionacea $\mathrm{L}$.}

León: Valderas, El Cuernico, 30TTN948636, $756 \mathrm{~m}$, thyme communities with roses on marly slope, 19-V-2015, P. Bariego \& F. del Egido (LEB 116822). Ibidem, 30TTN950635, thyme communities on marly soils, $765 \mathrm{~m}$ asl, 19-V2015, P. Bariego \& F. del Egido (LEB 116823); Cuadros, Camposagrado, 30TTN778318, grassland between the road and the plantation of pines, $1100 \mathrm{~m}$ asl, 19-V-2014, E. Puente \& F. del Egido (observed and photographed). Vega de Infanzones, 30TTN9106, P. Alvarez (LEB 115974).

Orchid included in the IEAPCL. We now enlarge considerably its provincial distribution 
area to the south and west. This species was just known in two localities close to one another in the east of the province: Mellanzos and Villalquite (Pérez Morales \& al., 1993), four dispersed points in southern foothill of eastern mountains (Díez Santos, 2011), and nearby León capital (Egido, 2012). All the populations we know, as well as the ones indicated by Díaz Santos (2011), are integrated by isolated specimens, with the exception of the Valderas one, which was such a large population.

Orchis provincialis Balb. ex Lam. \& DC.

León: Sobrado, between Aguiar and Portela de Aguiar, 29TPH7508, grassland inside a chestnut grove, $532 \mathrm{~m}$ asl, 29-IV-2014, F. del Egido \&. P. Bariego (observed and photographed).

Orchid included in both the IEAPCL and the LESRPE. In León province there only exist references in the northeast, in Picoeuropean valleys of Valdeón and Sajambre (Argüelles \& al., 2005, Alonso Felpete \& al., 2011, Díez Fernández, 2014). Its distribution area is now enlarged to the opposite side in the southwest of the province.

\section{Oxytropis foucaudii Gillot}

León: Cabrillanes, Torre de Babia, Picos Albos, 29TQH3365, orotemperate psicroxerophilous grassland (Festucion burnatii), $2000 \mathrm{~m}$ asl, 16-VII-2002, E. Puente (LEB 79999); Cabrillanes, Torre de Babia-La Riera, near Montigüero (Picos Albos), 29TQH3364, chionophilous basophilous grassland (Armerion cantabricae) dominated by Bellardiochloa violacea, $2162 \mathrm{~m}$ asl, 10-VIII-2010, E. Puente \&. F. del Egido (LEB 103952); San Emiliano, Torrebarrio, Pico Colines (Ubiña massif), 30TTN5869, chionophilous basophilous grasslands (Armerion cantabricae), $2077 \mathrm{~m}$ asl, 13-VII-2016, E. Puente \& F. del Egido (LEB 118026).

Pyrenean-Cantabrian endemism included in the IEAPCL. It is extremely rare in the Cantabrian Mountains, wherein there are only two nearby populations at Picos de Europa (León): Jou Santo and Peña Bermeja-Los Moledizos (Nava, 1984; Alonso Felpete \& al., 2011); and a few localities in territories of Babia and Somiedo: Picos Albos (Asturias) and Peñas de Orniz (León-Asturias) (Laínz, 1976); Mortera del Coto (Asturias), (Fernández Prieto, 1983) and La Cueta (León) (Puente \& al., 1985).
We just provided two new localities in Babia. The first of them includes four small subpopulations which own the same Asturian-Leonese population in the surroundings of Picos Albos and Peña Orniz. These now detected subpopulations consist of little individuals living together with $O$. halleri W.D.J. Koch, frequent in the area and with which hybridisation is possible. The population found in Ubiña massif is even scarcer, so that we can affirm that all the subpopulations in Babia are constituted by not many individuals (in La Cueta it is present but not as abundantly as is indicated in Puente \& al., (1985): the species which is abundant in this area is $O$. halleri). The situation is the same for the two populations of Picos de Europa. It would be recommended a protection status changing to 'Vulnerable' in the CEACL, based on the limited number of populations together with its population size.

At Pyrenees it seems to be more abundant, although is even considered as 'rare' in Huesca (Villar \& al., 1997) and as 'very rare' in Navarra (Aizpuru \& al., 1999). For all this, it should be evaluable the possibility of its inclusion in the LRFVE.

\section{Pulsatilla vernalis (L.) Mill.}

León: Cabrillanes, Torre de Babia, Picos Albos, 29TQH3365, chionophilous basophilous grasslands (Armerion cantabricae), $2100 \mathrm{~m}$ asl, 16-VII-2002, E. Puente (LEB 80015); Cabrillanes, Torre de Babia, near Montigüero, 29TQH334647, grassland in Calluna heath, $2087 \mathrm{~m}$ asl, 1-VII-2016, E. Puente \&. F. del Egido (observed and photographed); Cabrillanes-San Emiliano, Torre de Babia-La Majúa, Peña de Congosto, 29TQH357673, siliceous ridge, $2075 \mathrm{~m}$ asl, 29-VI-2003, M. de Godos (LEB 83311).

It is included in the IEAPCL. In León is only known of the northeast: Peña Prieta massif and nearby the Coriscao (Losa \& Montserrat, 1954; Alonso Redondo, 2003). The localities we now provide show an enlargement in its distribution area to the west.

Spergula rimarum Gay \& Durieu ex Lacaita. (=Spergula viscosa subsp. pourretii M. Laínz) León: San Emiliano, Riolago de Babia, Alto de Terreiros, 29TQH354551, silicicolous rupicolous community (Saxifragion willkommianae) in quarzytes, $2020 \mathrm{~m}$ asl, 28-VI2016, E. Puente \& F. del Egido (observed 
and photographed); San Emiliano, Torrebarrio, between Puerto de Ventana and Collada Canales or Socellares, 30TTN5672, silicicolous rupicolous communities (Saxifragion willkommianae and Sedion pyrenaici) in siliceous conglomerates, 1850-1860 m asl, 13VII-2016, E. Puente \& F. del Egido (observed and photographed).

It is included - as Spergula viscosa Lag.- in the IEAPCL and the LRFVE (under 'Vulnerable' category). It is an endemism of northwestern Spain, with scarce localities at Sierra del Teleno y Montes Aquilanos, Sierra de La Cabrera, Ancares, Omaña, Sierra de Villabandín, Laciana, Negrón del Puerto (Pinos) and Huergas de Babia (cf. Egido \& al., 2012a: 17).

We provide two new localities at lower Babia, the first of which is near the ones in Sierra de Villabandín (where we also saw it at the slope of Cabrillanes municipality: high Babia). This taxon results even scarcer than Spergula viscosa s. str., of which -in our opinion- is clearly independent.

Veronica micrantha Hoffmanns. \& Link.

León: San Miguel de las Dueñas, 29TQH01, 16-VI-1986, J. Andrés, LEB 46342 (ut. $V$. chamaedrys: rev. F. Llamas); Morales del Arcediano, 11-VIII-1977, F. Llamas (LEB 10396: ut. V. chamaedrys: rev. F. del Egido); Molinaferrera, 24-VI-1976, F. Llamas (LEB 3699 y 26818: ut. V. chamaedrys: rev. F. del Egido).

Endemism of Iberian northwest and centre-west, which is included in the CEACL, LRFVE (in both as 'Vulnerable'), LESRPE and in annexes II and IV of Habitat Directive. In León is only known the localities we have listed here, but there is not any specific bibliographic reference, just the provincial reference of Flora Iberica (Martínez Ortega \& al., 2009) based upon a duplicate of the first sheet that we have listed in this paper.

\section{References}

Aizpuru, I., Aseginolaza, C., Uribe-Echebarría, P.M., Urrutia, P. \& Zorrakin, I. (Eds.). 1999. Claves ilustradas de la flora del País Vasco y territorios limítrofes. $1^{\text {a }}$ ed. Serv. Centr. Publ. Gob. Vasc., VitoriaGasteiz.

Alonso Felpete, J.I., Robinson, S.G., Fernández, A., Sanzo, I., Mora, A., Bueno, A. \& Díaz, T.E. 2011. Catálogo florístico del Parque Nacional de los Picos de Europa. Doc. Jard. Bot. Atlántico (Gijón) 8: $1-310$.

Alonso Redondo, R. 2003. Valoración del estado de conservación de la vegetación y propuestas de ordenación y uso del territorio de la margen izquierda de la cuenca alta del río Esla (León). Ser. Tesis Doc. 2000. Secr. Publ. Med. Aud. Univ. León, León.

Amich, F \& Sánchez Rodríguez, J.A. 1988. Asientos para un atlas corológico de la flora occidental, 9. Mapa 84. Fontqueria 18: 7 y 18.

Anonymous. 1992. Directiva 92/43/CEE del Consejo de 21 de mayo de 1992 relativa a la conservación de los hábitats naturales y de la fauna y la flora silvestres. Diario Oficial de las Comunidades Europeas L206.

Anonymous. 2007a. Decreto 63/2007, de 14 de junio, por el que se crean el Catálogo de Flora Protegida de Castilla y León y la figura de protección denominada Microrreserva de Flora. BOCYL 119: 1319713204. Valladolid (parcialmente derogado).

Anonymous. 2007b. Ley 42/2007, de 13 de diciembre, del Patrimonio Natural y de la Biodiversidad. BOE 299: 51275-51327.

Anonymous. 2011. Real Decreto 139/2011, de 4 de febrero, para el desarrollo del Listado de Especies Silvestres en Régimen de Protección Especial y del Catálogo Español de Especies Amenazadas. BOE 46: 20912-20951.

Anonymous. 2015. Ley 4/2015, de 24 de marzo, del Patrimonio Natural de Castilla y León. BOCYL 61: 23956-24016.

Argüelles, J.M, Carlón, L., Gómez Casares, G., González del Valle, J.M., Laínz, M., Moreno Moral, G. \& Sánchez Pedraja, O. 2005. Contribuciones al conocimiento de la flora cantábrica, VII. Bol. Cien. Nat. RIDEA. 49: 147-193.

Benedí, C. 2009. Nothobartsia Bolliger \& Molau. In: Benedí, C., Rico, E., Güemes, J. \& Herrero, A. (Eds.). Flora iberica XIII. Pp. 505-508. R. Jard. Bot. CSIC, Madrid. 
Carlón, L., González del Valle, J.M., Laínz, M., Moreno Moral, G., Rodríguez Berdasco, J.M. \& Sánchez Pedraja, O. 2010. Contribuciones al conocimiento de la flora cantábrica, VIII. Doc. Jard. Bot. Atlántico (Gijón) 7: 1-95.

Carlón, L., Laínz, M., Moreno Moral, G., Rodríguez Berdasco, J.M. \& Sánchez Pedraja, Ó. 2014. Contribuciones al conocimiento de la flora cantábrica, IX. Doc. Jard. Bot. Atlántico 10: 1-153.

Castroviejo, S. (Coord.).1986-2010. Flora iberica. Plantas Vasculares de la Península Ibérica e Islas Baleares. R. Jard. Bot. CSIC, Madrid.

Díez Fernández, J. 2014. Apuntes sobre orquídeas en la Cordillera Cantábrica leonesa. Fl. Montiber. 56: 16-19.

Díez Santos, J.M. 2011. Guía de las orquídeas silvestres de la montaña oriental leonesa. Grupo de Acción Local de la Montaña de Riaño. 246 pp.

Egido, F. del. 2012. Flora y vegetación de la cuenca del río Torío (León). Cartografía y valoración de la vegetación: aplicaciones a la gestión y ordenación del territorio. Ser. Tesis Doc. Secr. Publ. Med. Aud. León. Univ. León. CD 932 pp + anex. 30 mapas vegetación actual 1.10000.

Egido, F. del, Puente, E. \& López Pacheco, M.J. 2007. De plantis legionensibus. Notula XXI. Lazaroa 28: $115-122$.

Egido, F. del, Fernández Cañedo, M., Puente, E. \& López Pacheco, M.J. 2012a. Notas sobre flora leonesa amenazada. Fl. Montiber. 51: 16-31.

Egido, F. del, Fernández Cañedo, M., Ferreras, N., Puente, E. \& López Pacheco, M.J. 2012b. Notas sobre flora leonesa amenazada, II. Lazaroa 33: 207-216.

Fernández Prieto, J.A. 1983. Aspectos geobotánicos de la Cordillera Cantábrica. An. Jard. Bot. Madrid 39(2): 489-513.

Galán Cela, P. 1993. Isatis L. In: Castroviejo, S. \& al. (Eds.). Flora iberica IV. Pp. 43-46. R. Jard. Bot. CSIC, Madrid.

Galán Cela, P., Gamarra, R. \& Garilleti, R. 1991. Asientos para un atlas corológico de la flora occidental, 18. Mapa 481. Fontqueria 31: 272-273.

García González, M.E., Puente, E., López Pacheco, M.J., Herrero, L. \& Penas, A. 1987. De plantis legionensibus. Notula X. Stud. Bot. Univ. Salamanca 6: 103-108.

Giménez de Azcárate, J. \& Amigo, J. 1996. Inventario da flora vascular de afloramientos calizos de Galicia (Pteridophyta e Spermatophyta). Cad. Ci. Biol. (Invs.), Sem. Est. Galegos 12: 1-181.

Laínz, M. 1960. Aportaciones al conocimiento de la flora cántabro-astur, IV. Bol. Inst. Est. Astur. Supl. C. $1: 3-42$.

Laínz, M. 1976. Sobre Oxytropis halleri Bunge ex Koch y O. foucadii Gillot en la Cordillera Cantábrica. Collect. Bot. (Barcelona) 10: 201-204.

Lence, C. 2009. Flora y vegetación del transecto Acebedo-Maraña-Mampodre (León). In: Llamas, F. \& Acedo, C. (Eds.). Botánica Pirenaico-Cantábrica en el siglo XXI. Pp. 457-528. Univ. León, León.

Lence, C., Alonso, A. \& Llamas, F. 2010. Nigritella gabasiana. Bases de Datos de Flora Vascular Silvestre y Cartografía Detallada de Hábitats de Castilla y León. 2001-2013. Junta Castilla y León. http://jcyll. plumtic.es/index.php/flora-protegida.

Losa, T.M. \& Montserrat, P. 1954. Nueva aportación al estudio de la flora de los montes cántabro-leoneses. An. Inst. Bot. Cavanilles 11(2): 385-462.

Martínez Ortega, M.M, Sánchez Agudo, J.A. \& Rico E. 2009. Veronica L. In: Benedí, C., Rico, E., Güemes, J. \& Herrero, A. (Eds.). Flora iberica XIII. Pp. 360-434. R. Jard. Bot. CSIC, Madrid.

Moreno, J.C. (Coord.). 2008. Lista Roja 2008 de la flora vascular española. Dir. Gen. Medio Nat. Polit. For. (M. Medio Amb. Medio Rur. Mar.) Soc. Esp. Biol. Conserv. Plant., Madrid. 86 pp.

Moreno, J.C. (Coord.). 2010. Lista Roja 2008 de la flora vascular española. Actualización con los datos de la Adenda 2010 al Atlas y Libro Rojo de la Flora Vascular Amenazada. Dir. Gen. Medio Nat. Polit. For. (M. Medio Amb. Medio Rur. Mar.) Soc. Esp. Biol. Conserv. Plant., Madrid. 46 pp.

Muñoz Centeno, M.L., Delgado L., López González, B., Rojas Andrés, B. \& Rico, E. 2009. Isatis platyloba. Bases de Datos de Flora Vascular Silvestre y Cartografía Detallada de Hábitats de Castilla y León. 20012013. Junta Castilla y León. http://jcyl1.plumtic.es/index.php/flora-protegida.

Nava, H.S. 1984. Una pequeña aportación a la flora picoeuropeana. Fontqueria 2: 1-8.

Nava, H.S., Fernández Casado, M.Á. \& Vera de la Puente, M.L. 1994a. Asientos para un Atlas Corológico de la Flora Occidental, 21. Mapa 566. Fontqueria 39: 346-347. 
Nava, H.S., Fernández Casado, M.A. \& Vera de la Puente, M.L. 1994b. Asientos para un Atlas Corológico de la Flora Occidental, 22. Mapa 566 (adiciones). Fontqueria 40: 112.

Nieto Feliner, G. 1987. El género Armeria (Plumbaginaceae) en la Península Ibérica: aclaraciones y novedades para una síntesis. An. Jard. Bot. Madrid 44(2): 319-348.

Pérez Morales, C., Herrero, L. García González, M.E., Puente, E. \& Penas, A. 1993. De plantis legionensibus. Notula XIV. Bot. Complutensis 18: 259-262.

Puente, E., López Pacheco, M.J. \& Díaz, T.E. 1985. De plantis legionensibus. Notula II. Acta Bot. Malacitana 10: 41-44.

Puente, E., López Pacheco, M.J., Llamas, F. \& Penas, A. 1995. Aportaciones al conocimiento del género Spergula L. Lagascalia 18(1): 15-24.

Villar, L., Sesé, J.A. \& Ferrández, J.V. 1997. Atlas de la Flora del Pirineo Aragonés. I. Consejo de Protección de la Naturaleza de Aragón e Instituto de Estudios Altoaragoneses. Huesca. 